\title{
James Watt
}

James Watt: Craftsman and Engineer

By H. W. Dickinson. Pp. xvi $+207+17$ plates. (Cambridge: At the University Press, 1936.) $10 s .6 d$. net.

THE appearance of this book is most opportune. Some such comparatively brief study of Watt has long been needed, for the large memorial volume on "James Watt and the Steam Engine", due to the collaboration of Mr. Rhys Jenkins and Mr. Dickinson, was never likely to be widely read, while the older work by Smiles, valuable as it still is, is out of date. Since Smiles wrote, a great mass of material connected with Watt and also with the famous firm of Boulton and Watt has become available, and this has led to a much closer study of a very important chapter in industrial history. A good deal of this material has found its way into the collections at the Science Museum, and as keeper of the Engineering Division Mr. Dickinson had the congenial task of studying and arranging the Watt exhibits there. His knowledge of the subject is therefore probably unique.

The particular aspect in which Watt is here shown is mainly that as a craftsman. "He was a craftsman at the outset of his career, craftsmanship helped him throughout his working life as inventor and engineer, and craftsmanship was the solace of his old age". If, however, this view of Watt is emphasised, it is not at the expense of his fundamental work on the steam engine. Watt may be said to have started life as an instrument maker and then, after practising for a time as a civil engineer, become a mechanical engineer through his genius for invention and the sheer force of circumstance. His inventive faculty drove him along a steep and rugged path, and one which by temperament he was ill-fitted to climb, but one which, nevertheless, thanks largely to the vision, resolution, support and business capacity of Boulton, led him to a contented old age in which he was free to give rein to his ingenuity without the vexatious contacts with rival inventors, blundering workmen and recalcitrant clients who were as thorns in his flesh.

Many-sided as were Watt's activities, undoubtedly the greatest interest in his life belongs to the twenty years 1765-1785, years of extraordinary difficulties. It was in this period that he transformed the crude, wasteful and often unreliable atmospheric engine of Newcomen into an engine applicable to many purposes, and so solved the urgent problem of power supply in industry. From his patents of $1769,1781,1782$ and 1784 came the double-acting rotatory engine which to some of his generation appeared likely to be the standard engine for all time. Each step in the development of the engine is clearly dealt with by Mr. Dickinson, whose story shows that an inventor may be a great benefactor, but often those who reap a harvest from his labours prove the hardest task-masters.

Mr. Dickinson begins his book with a short sketch of the industrial conditions and the position of craftsmen in Great Britain in Watt's early days, and some readers may regret that he does not conclude with a corresponding view of the country when Watt's work was done. The influence of Watt on the progress of industry was enormous. His contemporaries were in no doubt of this, and Lord Jeffrey remarked that it would be difficult to estimate the value which his inventions had conferred upon the country. Moreover, the Watt engine, he said, had "laid a sure foundation for all those future miracles of mechanical power which are to aid and reward the labours of after generations". This is one of the reasons why the pioneering work of Watt will remain of lasting interest.
Africa Dances :

a Book about West African Negroes. By Geoffrey Gorer. Pp. $\mathrm{xv}+363+32$ plates. (London: Faber and Faber, Ltd., 1935.) 15s. net.

Mr. GoRer has written a bright and entertaining account of a tour through all the French colonies of West Africa in the unconventional style which is fast becoming a convention. His object was to obtain a record of genuine native dances; and for this the companionship of a West African dancer, whom he met in Paris, gave him exceptional facilities. His descriptions of dances are full, though, of course, not technically adequate nor intended to serve for reproduction. A secondary interest, which some perhaps will think primary, is that as his intimate contacts were with the native rather than the official, his view of French methods of administration is taken at an unusual angle. His verdict is not flattering; and although he is not impressed favourably by the British, whom indeed he cordially dislikes, he contrasts the bearing and character of the Gold Coast native under British administration with that of the population of the French colonies very much to the advantage of the former. He attributes the difference almost entirely to the divergence in spirit and method of the two systems. 